\title{
Developing Critical Thinking through Activity -Based and Cooperative Learning Approach in Teaching High School Chemistry
}

\author{
Anabelie V. Valdez, Annaliza Lomoljo, Samsia P. Dumrang, and Manis M. Didatar
}

\begin{abstract}
The study aimed to develop critical thinking in chemistry using the Third International Mathematics and Science Survey Questionnaire (TIMSS-Like Test Items) and to lessen or eradicate misconception of students in the scientific concepts. A total of 99 third year Muslim students were selected and grouped into experimental and control group based on their respective section assignment. The experimental group underwent treatment using activity-based learning in a cooperative learning environment, while the control group used only the chalk and board discussions without hands-on. Three instruments were used namely: activities lifted from the TIMSS-R manual, the TIMSS-Like test items, and the selfassessment questionnaire. Both groups are exposed to pre- test and post-test after the conduct of the study. Findings revealed that the experimental group performed better than the control group. Majority of the students in the experimental group realized that the treatment motivated them to think critically. Through hands-on their misconceptions was corrected and lessened. Moreover, they also realized that the activity - based technique in the teaching - learning process is interesting, more fun and encouraging.
\end{abstract}

Index Terms-Misconception, activity - based learning, cooperative learning, critical thinking.

\section{INTRODUCTION}

Teaching is a profession of paramount importance both qualitatively and quantitatively important in serving education. The word education comes from the Latin word educere which means to bring out. So the educator is obligated not simply to bring out but to bring out the best among our students. It is deemed necessary that the educators must explore different pedagogy that could enhance students critical thinking, solved misconceptions and motivate the students to learn how to learn. Learners should constantly be challenged with tasks that refer to skills and knowledge just beyond their current level of mastery [1].

In a teaching model, the teacher will act as facilitator which sharply contrasts traditional teaching and facilitation of learning. As pointed out, a teacher tells, a facilitators asks; a teacher lectures from the front, a facilitator support from the back; a teacher gives answers according to a set of curriculum, a facilitator provides guidelines and creates the environment for the learner to arrive at his or her own

Manuscript received September 28, 2013; revised November 28, 2013.

Anabelie V. Valdez is with the Mindanao State University, Philippines (e-mail: anabelievillavaldez@gmail.com). conclusions; a teacher mostly gives monologue, a facilitator is in continuous dialogue with the learners. A facilitator should also be able to adapt the learning experience "in mid -air" by using his or her own initiative in order to steer the learning experience to where the learners want to create value [2]. There are critical attitudes to be developed by the students to develop higher order thinking skills, namely; intellectual honesty, deep respect for reason, commitment to mathematical and science principles, willingness to judge even against himself, love for truth, strong drive to clarity, accuracy, and self-confidence [3].

This study is based on the idea mentioned above that the teacher must be a facilitator of learning. To do this, activity - based through hands - on and cooperative learning is an important pedagogy to improve students' learning ability and interactive. Interactive learning process involves discursive, adaptive, interactive, and reflexive qualities. The social constructivist model emphasized the importance of the relationship between the student and the instructor in the learning process [4]. It is in this line that the researcher wanted to explore on how effective is the hands-on and activity-based teaching pedagogy of the teaching-learning process. Research on cooperative learning has shown that students, who have opportunities to work collaboratively, learn faster and more efficient, and with greater retention; they moreover feel more positive about their learning experience. The students will profit fully from interacting with others in an atmosphere of mutual respect and they learn to communicate ideas clearly, listen attentively, question courteously, and disagree with ideas from others $[5]$.

\section{RESEARCH METHODOLOGY}

\section{A. Participant of the Study}

A total of 99 third year high school students were involved in this study, 32 students in the experimental and control group, and 35 students serve as pilot group.

\section{B. Research Design and Methods}

This study is a combined quantitative -qualitative research design using quasi -experimental methods. Instruments used was a modules of different activities for hands-on, and evaluation test which is administered before and after the treatment, observation, interviews, journal logs, and respondents assessment on the intervention or treatment used in the research. 


\section{RESULTS}

\section{A. Pre-Test and Post-Test Profile}

Fig. 1 showed that the experimental and control performed almost equally during pre-test. However, in the post-test results, the experimental group performed better than the control group. The result indicated in this study had similar stand with the research findings of William about cooperative learning which he found out that cooperative learning is significantly better than the traditional method of teaching [6]. The score of students in the cooperative learning groups were about two-thirds of the standard deviation higher than the test scores of students in competitive or individualistic situations [5].

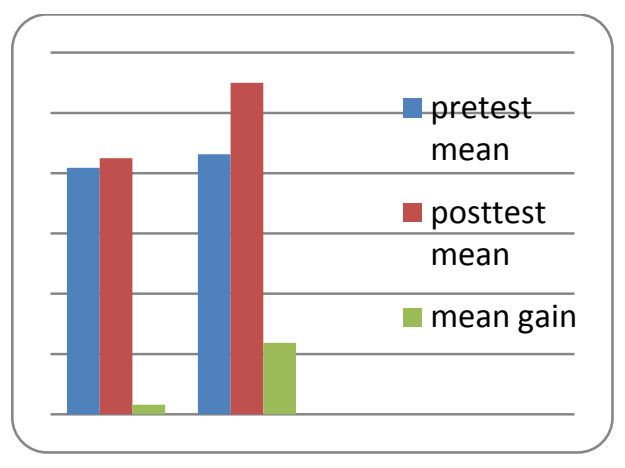

Fig. 1. Pre -test and post -test profile.

\section{B. Mean Score Relationship of the Respondents}

TABLE I: MEAN DifFERENCE DURING PRE-TEST AND POST-TEST

\begin{tabular}{|c|c|c|c|c|c|}
\hline Group & Mean & SD & $\vec{t}$ & Sig. & Decision \\
\hline Exp & 2.38 & 3.25 & -4.13 & 0.00 & $\mathrm{H}_{0}$ rejected \\
\hline Cont & 0.31 & 2.49 & -0.71 & 0.48 & $\mathrm{H}_{0}$ accepted \\
\hline Rel. & 2.5 & 4.12 & 3.43 & 0.002 & $\mathrm{H}_{0}$ rejected \\
\hline
\end{tabular}

\begin{tabular}{llclll}
\multicolumn{7}{c}{ TABLE II: CORRELATION OF MEANS } \\
\hline Group & Pre & Post & & \\
& Mean & Mean & $\boldsymbol{r}$ & sig & Decision \\
\hline Control & 8.18 & 8.5 & 0.22 & 0.224 & $\mathrm{H}_{0}$ accepted \\
Exp. & 8.6 & 11.0 & 0.57 & 0.001 & $\mathrm{H}_{0}$ rejected \\
\hline
\end{tabular}

As shown in Table I, the mean gain obtained by the experimental group showed significant difference, however, in the case of the control group, results revealed that their mean gain has no significant difference between pre-test and post-test scores. Comparing the mean gain between experimental and control group, results showed that there is a significant difference between their means.

Comparing the mean gain obtained by each group using Pearson Product Moment of Correlation, results revealed that there is no significant correlation between the means of the control group during pre-test and post-tests, while the experimental group showed significant correlation (Table II The positive correlation may imply that the treatment is effective. Studies conducted about cooperative learning revealed that cooperative method significantly influenced the attitude of the cooperative groups, learning style, and content knowledge. Moreover, cooperative group obtained significantly higher achievement on the post-test compared to the individualistic group in which this finding has similar stand with the findings of this recent study. Furthermore, cooperative learning is significantly better than the traditional method [6].

In the case of the misconception of the students, the misconception level of the respondents in the experimental group decreases during post-test compared to the control group. The decreased of the misconceptions level may be attributed by the treatment or intervention used by the experimental group which is the activity based learning techniques and cooperative learning approach.

Excerpts from the journal logs of the students in some of the items in the test were quoted:

Item 12: "Surface area and rate of burning"

For Control group;

- "The log chopped into smaller pieces are the chopped wood of slowly in the smaller pieces because the chopped wood is a slowly in the burn of the large wood"

For the Experimental Group;

- "A large log of wood will burn more slowly than the same log of wood chopped into smaller pieces because a large log of wood have small surface that oxygen insert. While the log of wood chopped into small pieces will burn faster than the large because it have a large surface to insert the oxygen."

Item 15: Relationship between temperature and volume;

For control group;

- "Because of the temperature and volume large because of the gas and more air combined to the balloons and the size was large"

For experimental group;

- 'The balloon rises because it exposed in the sun. It absorbed heat from the sun"

As noticed on the excerpt shown, experimental group developed their conceptual thinking and able to give reasons compared to the control group. This difference were attributed by the treatment underwent by the experimental group which is the activities in a cooperative learning environment. Cooperative or collaborative learning is said to increase student's learning because it is non-threatening, it creates low affective learning environment, it increases the amount of student participation in activities, and it reduces the sense of competitiveness, and reduces the teacher's dominance in the classroom. According to the constructivist point of view, knowledge depends on the situation and context, and learning is inherently a social activity. Constructivists suggest that learning must entail active inquiry, situated collaborative and cooperative approaches to learning [5].

Based on the assessment of the intervention as perceived by the respondents in the experimental group, majority of them said that the activity-based and cooperative learning techniques were above average and exciting. Eighty three percent $(83 \%)$ said that the activities make them think and it is more interesting and challenging. Sixty percent $(60 \%)$ of them believed that it clear out their misconnected ideas. With the use of activities and cooperative learning students were become more engaged in learning according to their pace and freedom of participation. Researcher said that "teacher can ensure that learning experiences incorporate 
problems that are important to students, not those that are primarily important to teachers and the educational system" [7].

Generally, overall impression of the respondents who underwent the treatment appreciated much with the techniques, the classroom setting and their academic freedom to share and explore with the different activities.

Thus it can be concluded that this technique is very useful for enhancing students ability to think and to lessen or avoid misconceptions of ideas that could be develop if the teachers will always use the traditional method of teaching. This technique enhances the thinking skills of the students. Teaching thinking provide students with meaningful purposeful activities and allowing them to work with experts who encourage them to see the world in particular ways [8]. On pedagogy, effective teaching occurs where the teaching experience structured by the teachers matches the needs of the learners. It includes tasks which develop the individual student's knowledge, skills, attitudes, and understanding in such a way that the students are applying past knowledge as appropriate in laying the foundation for the next stage of learning [9], [11]. Learning is an act of construction when students generate new meanings from incoming information by linking it with prior knowledge. This implies that less time is spent in interacting with apparatus, worksheets, and instruction, and more time devoted to reflection and discussion on some interactive activities [11].

It is then recommended that the teachers must be aware of the different pedagogy in teaching, explorative and interactive. Teachers must enhance their learning abilities, content knowledge and pedagogy through seminars, workshops, and further study. It is in this way that no one will be left behind since education is an un-ending journey.

\section{IMPLICATION}

On the basis of the pre-test and post-test profiles of the respondents, both groups performed better during post-test, compared to their pre-test performance, however, the experimental group excelled compared to the control group. This may be due to the hands-on activities provided in the modules and the cooperative learning set - up in the class. The small increased of their mean score may be attributed to the limited time of treatment and they might not be exposed to hands-on activities.

The significant increase of the means during pos-test in the experimental group implies that the respondents tried to answer the questions that involve higher order thinking skills. Furthermore, the misconception of the students were mostly corrected after the activities, maybe because they experience it, they discover, observed and explore the real events of each concept. The respondents in the experimental group said that the cooperative learning and activity - based modules and techniques are difficult but more exciting and challenging compared to purely discussions alone.

The positive impressions of the respondents in the experimental group about the activity -based and cooperative learning techniques implied that the students love to learn through hands-on, hearts - on, and minds-on teaching strategy. It implied further that more challenging roles help them develop their thinking skills. They only need enough time and cooperation so that one might help with the other.

\section{REFERENCES}

[1] J. H. Clarke, "Patterns of thinking," Needham Heights, Mass: Allyn and Bacon, 1991.

[2] R. G. T. Bellamy. (1999). Journal of Teacher Education. [Online]. 50. Available: http://www.questia.com

[3] O. M. Morco, "The construct of critical thinking in secondary school mathematics," UP Manila, Philippines, 1994.

[4] G. J. Green, "The critical thinking activities, abilities, and behaviours of freshmen in a university critical thinking course," Dissertation Abstract International, vol. 54, no. 8, 1994.

[5] K. William, "The effects of group cohesiveness on social loafing," presented at the annual meeting of the Midwestern psychological association, Detroit, 1981.

[6] D. W. Johnson and F. Johnson, "Cycles of learning: cooperation in the classroom," Alexandria, Va.: Association for Supervision and Curriculum Development, 1998.

[7] D. Tiene and A. Ingram, "Exploring current issues in educational technology," New York, Mcgraw - Hill Publication Co., 2001.

[8] A. L. Costa, Developing Minds, $2^{\text {nd }}$ ed., Alexandria, Virginia: Association for Supervision and Curriculum Development, 1999.

[9] P. Kelly, "Using thinking skills in primary classroom," Olivers Yard 55 City Round London, ASAGE Publication, 2005.

[10] M. Leask, "Learning to teach in secondary school: A comparison to school experience," London, New York, 1995.

[11] G. Green, "The critical thinking activities, abilities, and behaviours of freshmen in a university critical thinking course," Dissertation Abstract International, vol. 55, no. 8, 1994.

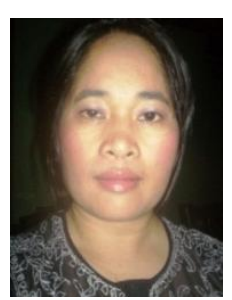

Anabelie V. Valdez was born at Aurora Zamboanga del Sur Philippines on March 16, 1975. She finished $\mathrm{PhD}$. Science education biology, Ph.D. educational management, Master's in secondary teaching general science and bachelor of Science secondary education biology in Mindanao State University Marawi City Philippines. She is the chairman in the academic committee at MSU-Balindong Community High School, a regular lecturer in the MSU SASE reviews, and lecturer in private review center for the licensure examination for teachers. She wrote 6 researcher related to educational innovations and one research about ethnoscience of indigenous people in Mindanao. Dr. Valdez is a member of the DOST-SEI scholar society and a licensed secondary biology teacher. She presented some papers in the international conference held in the Philippines namely; "World Research Festival", and the $5^{\text {th }}$ SSEASR on healing, religion and beliefs. Recently, she presented her paper in the 2013 IEDRC held at Jakarta Indonesia last July 13-14, 2013.

Anna Liza Lomoljo is a special assistant at the Office of the assistant vice chancellor for Academic Affairs, Mindanao State University Marawi City. She finished Ph.D. in Educational Management, MA in MAELT - English Language Teaching, MA in Public Administration and bachelor of Science in Public Administration in Mindanao State University Marawi City. She is an English lecturer at the College of Social Science and Humanities in the said University and a part -time faculty at the Jammiatu Muslim Mindanao Graduate School, Marawi City.

Samsia Paitao - Dumrang is a special assistant at the Office of the assistant vice chancellor for Academic Affairs, Mindanao State University Marawi City. She finished Ph.D. in Educational Management.

Manis M. Didatar is a former special assistant at the Office of the assistant vice chancellor for Academic Affairs, Mindanao State University Marawi City. Currently, she is the school principal in MSU-Balindong Community High School. She finished Master of Arts in School Administration and Specialized in Arabic Teaching. 